\title{
PRODUCTION AND ECONOMIC CHARACTERISTICS OF GOAT MANAGEMENT SYSTEMS IN VAVUNIYA DISTRICT, SRI LANKA
}

\author{
M. Sarmini ${ }^{1}$, S. Premaratne ${ }^{2}$ and S. Kalpana ${ }^{3}$ \\ ${ }^{I}$ Department of Animal Science, Faculty of Agriculture, University of Jaffna \\ ${ }^{2}$ Department of Animal Science, Faculty of Agriculture, University of Peradeniya \\ ${ }^{3}$ Veterinary Investigation Centre, Department of Animal Production and Health, Vavuniya \\ Email:*sarmini30@gmail.com
}

\begin{abstract}
A study was conducted to compare feeding and management strategies used in different goat management systems in Vavuniya district, Sri Lanka. A survey was carried out using 186 farmers (4 Veterinary divisions) from three different management systems, namely intensive, semiintensive and extensive management systems over a period of 4 months using a well-structured questionnaire. Data were analyzed using the Statistical Package for the Social Sciences (SPSS). Results indicated that majority $(71.51 \%)$ of farmers in the area considered goat farming as a part time business and $59.1 \%$ of women were involved in goat farming. Sixty one $\%$ of goat farmers had primary education and $37 \%$ had studied up to GCE $(\mathrm{O} / \mathrm{L})$ while the rest had completed GCE (A/L). Educational background did not significantly influence the profit of farmers. Hindu, Muslim and Christian communities were involved in goat farming where $64.5 \%$ of Hindus contributed to mutton industry. Between the three management systems, birth weight, slaughter weight and growth rate under intensive management and semi-intensive system were greater $(\mathrm{p}<0.05)$ compared to extensive system. Since the costs of feeding and labour involvement in intensive system were higher, the average monthly profit was lower $(\mathrm{p}<0.05)$ under intensive management system compared to extensive and semi-intensive management systems. Poor productivity, lack of grazing land, high feed and labour cost and lack of loan facilities were identified as the major constraints in goat production in the area. Comparing all production and economic parameters, it can be concluded that goat farming under semi-intensive management system was more profitable than intensive and extensive management system in Vavuniya district.
\end{abstract}

Keywords: Goat management systems, Production and economic parameters of goats

\section{Introduction}

Total recent goat counts of Sri Lanka are 266,750 (Department of Census and Statistics, Sri Lanka, 2016). The majority is concentrated in the dry and dry intermediate zones of Sri Lanka. A large share of the goat counts is concentrated in the districts of Jaffna, Batticaloa, Trincomalee, Mannar, Vavuniya, Anuradhapura and Amparai in the dry zone and Kurunegala and Puttalam in the intermediate zone (Department of Census and Statistics, Sri Lanka, 2016). The majority of goats reared are indigenous goats and crosses with improved breeds such as Jamunapari, Beetal, and Boer (Rajaguru, 1988). Indigenous goats produce less milk and are mainly reared for meat. However, the wealth of the indigenous goat could be improved by giving little attention (Mahusoon and Sivarajah, 1999). The annual per capita consumption of goat meat in Sri Lanka in 2015 was about $0.09 \mathrm{~kg}$ (Department of Animal Production and Health, 2015). The total annual domestic production of mutton was 1350 MT in the year 2015 the balance requirement (350.33 MT) is imported (Department of Animal Production and Health, 2015).

Goat is an important species in the livestock-farming sector of Sri Lanka and it contributes to the economic development of the country. Goat farming is one of the most affordable and sustainable ways of enhancing rural household income, especially in the areas where crop and dairy farming are not economical (Mahusoon and 
Sivarajah, 1999). Therefore, it is important to assess the strengths and weaknesses of prevailing goat management systems in the country so that short term and long term measures can be taken to improve the goat production in the country. Goat population of Vavuniya in 2016 was 11,810 (4.3\% of total of the island) (Department of Census and Statistics, Sri Lanka, 2016). The low rainfall pattern and temperature of the district are much favourable for goat farming (Ministry of livestock and rural communityReport, 2011).

The main objective of the present study was to investigate the characteristics of available feeding and management strategies used in different goat management systems in Vavuniya District to estimate expenses and income of goat farming under different management systems so that recommendations could be given to improve the production in the area.

\section{Methodology}

The study was conducted in Vavuniya District in the dry zone of Sri Lanka. Average elevation of the area is 104 $\mathrm{m}$ above the sea level, whereas the average rainfall in the study area was less than $1500 \mathrm{~mm}$ per year (Ministry of Livestock and Rural Community Report, 2011).

\section{Data collection}

The study included goat farmers in four veterinary divisions, namely Vavuniya, Vavuniya south, Vavuniya north and Chedikulam. According to the information available in the Veterinary office, there were 153 registered goat farms having 952 goats in these four divisions. The farmers of extensive management and semiintensive system were selected at random whereas all the intensive farmers in four veterinary divisions were used for the survey. Therefore, 80 farmers were selected under the extensive management system, 89 farmers under the semi-intensive management system and all (17) farmers from the intensive management system.

Data were collected using a pre-tested structured questionnaire which had the following information: owners general information, herd size, herd composition, available breeds, management system, breeding method, birth weight, slaughter weight, slaughter age, cost and income details during the period from January to April 2017. Each respondent was given a brief description of the nature and purpose of the study at the beginning of the interview. Responses of farmers were recorded directly on the questionnaires.

\section{Data analysis}

Obtained data were analyzed using the Statistical Package for the Social Sciences (SPSS). Mean comparisons were applied by the Least Significant Difference (LSD) wherever appropriate.

\section{Results and Discussion}

\section{Socio-economics of goat farmers}

General observations of goat farmers in Vavuniya District are shown in Table 1. Results indicated that 65\% of the goat farmers were Hindu and $25 \%$ of farmers were Islam in the area. Goat farming was a part time business for many farmers in these four veterinary divisions and most of them were engaged in crop cultivation. They were traditional farmers, but a low interest was shown on goat farming because of the low income. Women played a major role (59\%) in goat farming in the area, including feeding and management of goats as well as looking after the children in their family. Nearly $61 \%$ of farmers were educated up to grade 5 , while $37 \%$ were educated up to G.C.E. (O/L) and, only $3 \%$ were up to G.C.E. (A/L) in the study area indicating that highest percentage of farmers was educated up to primary level. According to the survey, $78 \%$ of goats were of indigenous type, followed by $14.5 \%$ Jamunapari cross, $5.7 \%$ Jamunapari and 1.8\% of Saanen. Most popular 
goat breeds in the region were indigenous type and they were extensively managed, while other breeds were reared intensively and semi-intensively.

Table 1. General observations of goat farmers in Vavuniya District

\begin{tabular}{ll}
\hline Variable & Percentage \\
\hline Sex & \\
Male & 40.9 \\
Female & 59.1 \\
\hline Age (Years) & \\
20-30 & 3.2 \\
$30-40$ & 20.4 \\
$40-50$ & 62.4 \\
50-60 & 14.0 \\
\hline Religion & \\
Hindu & 64.5 \\
Islam & 25.3 \\
Christian & 10.2 \\
\hline Educational Level & \\
Grade 1 - 5 & 60.8 \\
G.C.E. (O/L) & 36.5 \\
G.C.E. (A/L) & 2.7 \\
Higher Education & 0 \\
\hline Breeds of goat & \\
Jamunapari & 5.7 \\
Jamunapari cross & 14.5 \\
Saanen cross & 1.8 \\
Indigenous & 78.0 \\
\hline Management practices & \\
Extensive system & 9.1 \\
Semi-Intensive system & \\
Intensive system & \\
\hline
\end{tabular}

\section{Herd size and composition}

Herd size and composition of goats under different management systems are shown in Table 2.

Table 2. Average herd size and composition of goats under different management systems ${ }^{\dagger}$

\begin{tabular}{llll}
\hline Variable & \multicolumn{2}{l}{ Management system } & \\
\cline { 2 - 4 } & Intensive & Semi-intensive & Extensive \\
\hline Herd size & $14.5^{\mathrm{b}} \pm 1.24$ & $19.9^{\mathrm{ab}} \pm 1.85$ & $23.9^{\mathrm{a}} \pm 1.74$ \\
\hline Male & $1.94^{\mathrm{b}} \pm 0.18$ & $3.18^{\mathrm{b}} \pm 0.48$ & $5.62^{\mathrm{a}} \pm 0.50$ \\
\hline Female & $7.76^{\mathrm{a}} \pm 0.99$ & $11.3^{\mathrm{a}} \pm 1.01$ & $10.6^{\mathrm{a}} \pm 0.78$ \\
\hline Kids (under six months of age) & $4.82^{\mathrm{b}} \pm 0.68$ & $5.53^{\mathrm{ab}} \pm 0.54$ & $7.79^{\mathrm{a}} \pm 0.59$ \\
\hline${ }^{\dagger}$ Mean \pm Standard Error & & \\
${ }^{\mathrm{a}, \mathrm{b}}$ Means with different superscripts within a raw are significantly different $(\mathrm{p}<0.05)$ &
\end{tabular}


The mean herd size under intensive, semi-intensive and extensive management systems were 15, 20 and 24 Animals/farm, respectively (Table 2) and the means of intensive and extensive systems are significantly different $(\mathrm{p}<0.05)$. Number of male goats and kids in extensive management system were significantly greater $(p<0.05)$ compared to those in the intensive system (Table 2). The percentage of male goats in the herd was less compared to female goats under all management systems because excess male animals were sold to fulfill household requirements. A limited number of male goats were kept for the breeding purposes of the herd.

\section{Effect of farm management system on birth weight, growth rate and slaughter weight of goats}

According to the Table 3, goats in the intensive management system had significantly greater $(\mathrm{p}<0.05)$ birth weight compared to extensive and semi-intensive management system. Birth weight of kids under extensive management system was half $(\mathrm{p}<0.05)$ than that of intensive management system and this may be related to the poor feeding and management practices used under extensive management system. Furthermore, goats under extensive management system were mainly of indigenous type whereas indigenous type, Jamunapari and Saanen crosses were used under semi-intensive and intensive management system. This could also have an effect on the lower birth weight of kids under extensive management system compared to intensive and semiintensive management system.

Table 3. Effect of management systems on performance of goats ${ }^{\dagger}$

\begin{tabular}{llll}
\hline \multirow{2}{*}{ Variable } & \multicolumn{2}{l}{ Management system } \\
\cline { 2 - 4 } & Intensive & Semi-intensive & Extensive \\
\hline Birth weight $(\mathrm{kg})$ & $3.16^{\mathrm{a}} \pm 0.13$ & $2.27^{\mathrm{b}} \pm 0.06$ & $1.73^{\mathrm{c}} \pm 0.03$ \\
\hline Slaughter weight $(\mathrm{kg})$ & $38.6^{\mathrm{a}} \pm 10.25$ & $28.3^{\mathrm{b}} \pm 7.06$ & $25.8^{\mathrm{b}} \pm 3.32$ \\
\hline Mean growth rate $(\mathrm{kg} / \mathrm{month})$ & $2.57^{\mathrm{a}} \pm 0.07$ & $1.62^{\mathrm{b}} \pm 0.14$ & $1.32^{\mathrm{b}} \pm 0.30$ \\
\hline Mean slaughter age (month) & $13.8^{\mathrm{a}} \pm 0.37$ & $16.1^{\mathrm{b}} \pm 2.49$ & $18.2^{\mathrm{c}} \pm 0.75$ \\
\hline${ }^{\dagger}$ Mean \pm Standard Error & & & \\
${ }^{\mathrm{l}, \mathrm{b}, \mathrm{c}}$ Means with different superscripts within a raw are significantly different $(\mathrm{p}<0.05)$
\end{tabular}

As per Hariharan et al (1991), the average birth weight of goats in the dry zone was $1.29 \pm 0.3 \mathrm{~kg}$. The reason for poor birth weights observed in the extensive system might be due to the low genetic potential, poor nutrition management, poor growth rate and productivity (Subasinghe, 2014). Furthermore, slaughter weight of goats under intensive management system was greater $(\mathrm{p}<0.05)$ than the semi-intensive and extensive management system even though the slaughter age was less than that of semi-intensive and extensive management system.

The growth rate of goats under intensive management system was double than that of extensive management system which is almost 1.5 fold greater $(\mathrm{p}<0.05)$ compared to semi-intensive management system. The reason for this may be that the nutritive value of fodder consumed by goats under semi-intensive and extensive management system was poor compared to intensively managed goats. Goats managed under intensive system received more concentrates from the diet and, quality and quantity of fodder was somewhat uniform throughout the growing period. Therefore, mean slaughter age of goats under intensive management system was earlier compared to extensive management system. Birth weight, slaughter weight and growth rate of goats under semiintensive system were greater ( $p>0.05$ ) compared to extensive management system. Goats managed under semiintensive system received some amount of concentrate from the diet. Further, some amount of improved breed crosses is reared in the semi-intensive management system. These may be the reasons for the better performance of the goats in the semi-intensive system compared to extensive management system. 


\section{Farm income}

The expenditure, annual gross income and profit per farm under three management systems are presented in Table 4. The main income from goat farming was through selling of goats for meat, selling of goat manure as a fertilizer and selling of milk. According to the Table 4, a lower $(p<0.05)$ income was generated by the extensively managed farms compared to intensive and semi-intensive management system. The expenditure under these three management systems consisted of cost of concentrate, minerals and de-worming, labour and veterinary services. The results of the study indicated that the average total annual expenditure per farm under extensive management system was Rs. 6980 lower $(\mathrm{p}<0.05)$ than intensively management system, particularly due to significantly lower $(\mathrm{p}<0.05)$ labour cost and concentrate feed cost.

Table 4. Income and expenditure of the goat farmers under different management systems $(R s)^{\dagger,}$

\begin{tabular}{llll}
\hline & \multicolumn{2}{l}{ Management system } & \\
\cline { 2 - 4 } Variables & Intensive & Semi-intensive & Extensive \\
\hline Income & & & \\
Sale of animals & $172941^{\mathrm{a}} \pm 16927$ & $127903^{\mathrm{b}} \pm 12159$ & $85750^{\mathrm{c}} \pm 6749$ \\
Sale of fertilizer and milk & $42029^{\mathrm{a}} \pm 4155$ & $33844^{\mathrm{b}} \pm 2317$ & $2560^{\mathrm{c}} \pm 729$ \\
\hline Total income & $214970^{\mathrm{a}} \pm 18083$ & $161747^{\mathrm{b}} \pm 13060$ & $88310^{\mathrm{c}} \pm 7027$ \\
\hline Expenditure & & & \\
Concentrate & $47124^{\mathrm{a}} \pm 18083$ & $47035^{\mathrm{a}} \pm 3998$ & $3614^{\mathrm{b}} \pm 1060$ \\
Mineral and De worming & $9095^{\mathrm{a}} \pm 1394$ & $3111^{\mathrm{b}} \pm 500$ & $1017^{\mathrm{c}} \pm 1060$ \\
Veterinary service & $3306^{\mathrm{a}} \pm 559$ & $2106^{\mathrm{ab}} \pm 509$ & $1484^{\mathrm{b}} \pm 275$ \\
Labour & $142023^{\mathrm{a}} \pm 13999$ & $3069^{\mathrm{b}} \pm 2931$ & $863^{\mathrm{b}} \pm 741$ \\
\hline Total expenditure & $201460^{\mathrm{a}} \pm 19434$ & $55411^{\mathrm{b}} \pm 5406$ & $6979^{\mathrm{c}} \pm 1274$ \\
\hline Net profit/year & $13420^{\mathrm{c}} \pm 1504$ & $106425^{\mathrm{a}} \pm 9838$ & $81331^{\mathrm{b}} \pm 6732$ \\
\hline Net profit/month & $1118^{\mathrm{c}} \pm 253$ & $8868^{\mathrm{a}} \pm 819$ & $6777^{\mathrm{b}} \pm 492$ \\
\hline
\end{tabular}

${ }^{\dagger}$ Mean \pm Standard Error

${ }^{\mathrm{a}, \mathrm{b}, \mathrm{c}}$ Means with different superscripts within a raw are significantly different $(\mathrm{p}<0.05)$

Although income was less, farmers in semi-intensive and extensive management systems reported a significantly higher $(\mathrm{p}<0.05)$ average profit margin per farm compared to those who have practised intensive management system.

Goat farming is an important source of income for the small scale goat farmers in Vavuniya District. Majority of the farmers of the extensive management system depend on free grazing, due to their main source of animal feed while some other concentrates were fed to goats of the semi-intensive and intensive management systems. The average household income was higher in the intensive management system. However, monthly expenditure was also higher in the intensive system and therefore, net profit obtained in the semi-intensive management system was higher than the intensive and the extensive management system.

Poor production of animal, lack of grazing land, high feed and labour cost and lack of loan facilities were identified as the major constraints in goat production in the area. In order to improve the goat production in Vavuniya District, following suggestions can be given; introduce more strategic feeding during the dry period, improvement of breeding using superior breeds of goats, improvement of health care facilities and proper marketing facilities to sell animals. Thus, it is important to educate the farmers on these aspects as well as scientific goat management in the study area to improve the productivity of goats. 


\section{Conclusions}

It can be concluded that goat farming in semi-intensive management system was more profitable compared to the intensive and the extensive management system in Vavuniya District.

\section{References}

Department of Animal Poduction and Health, 2015, Goat Industry - Key Statistics, Date of access: 01/07/2017 http://www.daph.gov.lk/web/index.php?option=com_content\&view=article\&id=34\&Itemid=141\&lang=en\#goat -industry-2015.

Department of Census and Statistics, 2016, Colombo, Sri Lanka, Date of access: 15/05/2017 http://www.statistics.gov.lk/agriculture/Livestock/LivestockStatistics.html.

Hariharen., R, Ravindran., S and Ravindran., V., 1991.Goat production under traditional management systems in Batticaloa district. Proc. of the 4th Annual Sessions of the SLAAS.

Hariharan, R. and Sivarajah, P., 1993. Improving productivity of indigenous goat species through better management in Eastern Sri Lanka. Regional Animal Production and Health Commission of the FAO, Bangkok, Thailand. Asian Livestock, 18 (1).

Mahusoon, M.M. and Sivarajah,P.,1999, Improving Goat Production in the 'Coconut Triangle' of Sri Lanka, Agrieast 1(1), 67-74.

Ministry of livestock development and rural community development, 2011, Livestock master plan "A strategy for livestock development for self - sufficiency", published by Ministry of livestock and rural community development,(Mirihana Nugegoda: Printers establishment (pvt) LTD), pp 103-106.

Rajaguru, A.S.B. 1988. Goat meat production in Sri Lanka, Proceedings of the Goat Meat Production in Asia,Tando Jam, Pakistan, March, pp 179-187.

Subasinghe, D.H.A., 2014, Small ruminant industry in Sri Lanka - Part III, S.L.Vet.J, 61(B): 15-26. 


\section{Appendix}

Table 1. General observations of goat farmers in Vavuniya District

\begin{tabular}{ll}
\hline Variable & Percentage \\
\hline Sex & \\
Male & 40.9 \\
Female & 59.1 \\
\hline Age (Years) & \\
20-30 & 3.2 \\
$30-40$ & 20.4 \\
$40-50$ & 62.4 \\
50-60 & 14.0 \\
\hline Religion & \\
Hindu & 64.5 \\
Islam & 25.3 \\
Christian & 10.2 \\
\hline Educational Level & \\
Grade 1 - 5 & 60.8 \\
G.C.E. (O/L) & 36.5 \\
G.C.E. (A/L) & 2.7 \\
Higher Education & 0 \\
\hline Breeds of goat & \\
Jamunapari & 5.7 \\
Jamunapari cross & 14.5 \\
Saanen cross & 78.0 \\
Indigenous & \\
\hline Management practices & \\
Extensive system & \\
Semi-Intensive system & \\
Intensive system & \\
\hline
\end{tabular}

Table 2. Average herd size and composition of goats under different management systems ${ }^{\dagger}$

\begin{tabular}{llll}
\hline Variable & \multicolumn{3}{c}{ Management system } \\
\cline { 2 - 4 } & Intensive & Semi-Intensive & Extensive \\
\hline Herd size & $14.5^{\mathrm{b}} \pm 1.24$ & $19.9^{\mathrm{ab}} \pm 1.85$ & $23.9^{\mathrm{a}} \pm 1.74$ \\
\hline Male & $1.94^{\mathrm{b}} \pm 0.18$ & $3.18^{\mathrm{b}} \pm 0.48$ & $5.62^{\mathrm{a}} \pm 0.50$ \\
\hline Female & $7.76^{\mathrm{a}} \pm 0.99$ & $11.3^{\mathrm{a}} \pm 1.01$ & $10.6^{\mathrm{a}} \pm 0.78$ \\
\hline Kids & $4.82^{\mathrm{b}} \pm 0.68$ & $5.53^{\mathrm{ab}} \pm 0.54$ & $7.79^{\mathrm{a}} \pm 0.59$ \\
\hline
\end{tabular}

${ }^{\dagger}$ Mean \pm Standard Error

${ }^{\mathrm{a}, \mathrm{b}}$ Means with different superscripts within a raw are significantly different $(\mathrm{p}<0.05)$ 
Table 3. Effect of management systems on performance of goats ${ }^{\dagger}$

\begin{tabular}{lllr}
\hline \multirow{2}{*}{ Variable } & \multicolumn{3}{l}{ Management system } \\
\cline { 2 - 4 } & Intensive & Semi-intensive & Extensive \\
\hline Birth weight $(\mathrm{kg})$ & $3.16^{\mathrm{a}} \pm 0.13$ & $2.27^{\mathrm{b}} \pm 0.06$ & $1.73^{\mathrm{c}} \pm 0.03$ \\
\hline Slaughter weight $(\mathrm{kg})$ & $38.6^{\mathrm{a}} \pm 10.25$ & $28.3^{\mathrm{b}} \pm 7.06$ & $25.8^{\mathrm{b}} \pm 3.32$ \\
\hline Mean growth rate $(\mathrm{kg} /$ month $)$ & $2.57^{\mathrm{a}} \pm 0.07$ & $1.62^{\mathrm{b}} \pm 0.14$ & $1.32^{\mathrm{b}} \pm 0.30$ \\
\hline Mean slaughter age (month) & $13.8^{\mathrm{a}} \pm 0.37$ & $16.1^{\mathrm{b}} \pm 2.49$ & $18.2^{\mathrm{c}} \pm 0.75$ \\
\hline
\end{tabular}

${ }^{\dagger}$ Mean \pm Standard Error

${ }^{a, b, c}$ Means with different superscripts within a raw are significantly different $(\mathrm{p}<0.05)$

Table 4. Income and expenditure of the goat farmers under different management systems (Rs. $)^{\dagger}$

\begin{tabular}{|c|c|c|c|}
\hline \multirow[b]{2}{*}{ Variables } & \multicolumn{3}{|c|}{ Management system } \\
\hline & Intensive & Semi-intensive & Extensive \\
\hline \multicolumn{4}{|l|}{ Income } \\
\hline Sale of animals & $172941^{\mathrm{a}} \pm 16927$ & $127903^{\mathrm{b}} \pm 12159$ & $85750^{c} \pm 6749$ \\
\hline Sale of fertilizer and milk & $42029^{\mathrm{a}} \pm 4155$ & $33844^{b} \pm 2317$ & $2560^{c} \pm 729$ \\
\hline Total income & $214970^{\mathrm{a}} \pm 18083$ & $161747^{b} \pm 13060$ & $88310^{c} \pm 7027$ \\
\hline \multicolumn{4}{|l|}{ Expenditure } \\
\hline Concentrate & $47124^{a} \pm 18083$ & $47035^{\mathrm{a}} \pm 3998$ & $3614^{b} \pm 1060$ \\
\hline Mineral and De worming & $9095^{\mathrm{a}} \pm 1394$ & $3111^{\mathrm{b}} \pm 500$ & $1017^{\mathrm{c}} \pm 1060$ \\
\hline Veterinary service & $3306^{\mathrm{a}} \pm 559$ & $2106^{\mathrm{ab}} \pm 509$ & $1484^{b} \pm 275$ \\
\hline Labour & $142023^{\mathrm{a}} \pm 13999$ & $3069^{\mathrm{b}} \pm 2931$ & $863^{\mathrm{b}} \pm 741$ \\
\hline Total expenditure & $201460^{\mathrm{a}} \pm 19434$ & $55411^{\mathrm{b}} \pm 5406$ & $6979^{c} \pm 1274$ \\
\hline Net profit/year & $13420^{\mathrm{c}} \pm 1504$ & $106425^{\mathrm{a}} \pm 9838$ & $81331^{\mathrm{b}} \pm 6732$ \\
\hline Net profit/month & $1118^{\mathrm{c}} \pm 253$ & $8868^{\mathrm{a}} \pm 819$ & $6777^{\mathrm{b}} \pm 492$ \\
\hline
\end{tabular}

${ }^{\dagger}$ Mean \pm Standard Error

${ }^{\mathrm{a}, \mathrm{b}, \mathrm{c}}$ Means with different superscripts within a raw are significantly different $(\mathrm{p}<0.05)$ 